\title{
Appropriation as a Form of Nationalism? Collecting French Furniture in the Nineteenth Century
}

\author{
Adriana Turpin
}

During the "long" nineteenth century, at a time when Britain reached its greatest economic and political power, the taste for the furnishing and decoration of the houses of the aristocrats and nouveaux riches was resolutely French. Moreover, it was the France of the eighteenth century that was recaptured in the boudoirs, drawing and reception rooms of the great London mansions and country residences. The history of this phenomenon can be traced back to the late eighteenth century, when British and Irish aristocrats travelled to France to acquire firstly contemporary and then antique works of art. The period ends with the advent of the Great War and the demise of the great London and country houses. By this time, as J. Mordaunt Crook in The Rise of the Nouveaux Riches describes, central London, Mayfair, Park Lane and Piccadilly were filled with the houses of the newly rich; he gives a breathless account of an astonishing number of houses furnished in the eighteenth-century style, often by French architects and designers or architects of French origin. ${ }^{1}$ Although the style was clearly associated with ostentation and wealth, acquiring or collecting French furniture also appealed to the connoisseur, who could admire the quality and superb craftsmanship of the works of art collected. In addition to the well-known and very rich collectors, eighteenth-century French furniture and porcelains were acquired at all levels of British society, as can be seen in the quantity of French furniture in nineteenth-century sale catalogues of 'a gentleman' or a 'householder.' ${ }^{2}$ During the nineteenth century for the first time

1 Joseph Mordaunt Crook, The Rise of the Nouveaux Riches: Style and Status in Victorian and Edwardian Architecture (London: John Murray, 1999), 153-212.

2 For the purpose of this essay, in addition to sale catalogues from Christie's, Manson \& Woods, the author searched more than 100 catalogues produced by the auction company Foster and Sons between 1826 and 1850, held at the National Art Library in the Victoria \& Albert Museum. These cover sales held weekly at the auction rooms at 54 Pall Mall of the contents of what appear to be mid-level households. The question of who we could consider "middle class" is complicated, but as the catalogues show, French furniture appears in a wide variety of sales throughout the century. I would like in particular to thank Eunmin Lim, who transcribed many of these auction catalogues, and Preston Fitzgerald, for his assistance in researching the catalogues in Christie's archives.

(C) ADRIANA TURPIN, 2019 | DOI:10.1163/9789004291997_009

This is an open access chapter distributed under the terms of the prevailing CC-BY-NC License at the time of publication. 
there was a market for old or antique furniture and porcelains. This may, at the outset, largely have been the result of the driving opportunism of French and British dealers resulting from sales during and after the Revolution in France. It became a national phenomenon as the 'old French style' - as it was often called - grew into an accepted form of decoration and furnishing of the drawing rooms of Britain. The market for French works of art (or copies thereof) remained strong well into the twentieth century.

Whereas the appeal of this style in Britain is well studied and described, the underlying question of the market forces steering this long-lasting taste has never been properly analysed; nor have the drivers for this taste been discussed in the context of a transnational exchange. ${ }^{3}$ The popular market for French furniture might also raise questions in an era dominated by British nationalism that often expressed itself as anti-French. This article allows for reflection on the hitherto unclear interplay between market forces and taste patterns, and in particular it opens the opportunity to analyse the dichotomy of adopting a "foreign" style during a period of intense national pride and great national wealth, beyond mere copying or imitation of a fashionable style. What began as the taste of the richest and most aristocratic families became fashionable amongst the growing bourgeoisie, promulgated by the sales of French furniture and then by the magazines and journals devoted to design and taste. What was derided at the beginning of the century had become acceptable and even praiseworthy by the end of the century, as a manifestation of the international and cosmopolitan. In this essay I would like therefore to consider the market for French furniture in the nineteenth century and examine the enduring taste for the French Ancien Régime style throughout the century within the context of the debates on British identity.

The concept of nationhood, national identity, Britain's role as a colonial empire and the manifestation of this identity were all areas of intense debate and scrutiny during the nineteenth century. A key construct in the formation of national identity is the argument that Benedict Anderson has discussed in Imagined Communities, namely that the idea of nationhood grows out of the

3 See in particular: Nicholas Cooper, The Opulent Eye: Late Victorian and Edwardian Taste in Interior Design (London: Architectural Press, 1976); Edwin Beresford Chancellor, The Private Palaces of London, Past and Present (London: K. Paul Trench, Trübner \& Co. Ltd., 1908); Christopher Symon Sykes, Private Palaces: Life in the Great London Houses (London: Chattus \& Windus, 1985), 250-319. For an account of the taste of the South African millionaires and their collecting, see: Michael Stevenson, Art and Aspirations: The Randlords of South Africa and their Collections (Vlaeberg: Fernwood Press, 2002). 
creation of communal entities. ${ }^{4}$ Although he is referring to the contemporary emergence of new nations, his analysis can be applied to the historic emergence of the nation during the nineteenth century and developed to demonstrate that the appropriation of a French decorative style was part of the developing consciousness of the nation. In this context-and as will be shown in detail later-it can be argued that acquiring and displaying French works of art moved from the prerogative of aristocratic elites to an acceptable demonstration of British wealth and national pride. As this essay demonstrates, adopting the French alternative had a significant and widespread appeal to the wealthy and indeed the not-so-wealthy. This is all the more significant as there were two other historicist revivals taking place in Britain at the same time: the Gothic revival, championed as the historical national style, and that of the Italian Renaissance. Much admired for its associations with humanism and the individual, Renaissance art was collected by those who often described themselves as the heirs of the Medici and other great mercantile princes. In contrast to the Italian Renaissance, the market for French decorative arts was to be found in the aristocratic origins of this taste. Thus a major factor in its acceptance was its international nature, connecting figures not only in France and England, but also in Germany, Italy and indeed throughout most of Europe. It is also important to note that the revival of the French eighteenth century was not confined to Britain, but was part of an aristocratic style found all over Europe. In Germany many palaces were decorated in a revived rococo style, particularly those created for Emperor Ludwig iI (1845-86). At Linderhoff (1869-78) the interiors drew on the rococo decorations of the Munich Residenz of Nymphenburg as much as on French design; at Herrenschiemsee Palace (1878, and still uncompleted in 1886) Ludwig created a new Versailles. ${ }^{5}$

4 Benedict Anderson, Imagined Communities: Reflections on the Origin and Spread of Nationalism (London: Verso, 1983).

5 Ken Ireland, Cythera Regained: The Rococo Revival in European Literature and the Arts, 1830-1910 (Madison: Fairleigh Dickinson University Press, 2006), 139-41. Discussions as to the relevance of the eighteenth century to nineteenth-century identity and taste were as intense on the Continent as in Britain. Discussion on the style as a matter of historic precedents include: Gotfried Semper, Der Stil in den technischen und tektonischen Künsten, vol. 2 (Munich: F. Bruckmann, 1860), 350; Anton Springer, "Der Rococostil," in Id., Bilder aus der neueren Kunstgeschichte, vol. 2 (Bonn: A. Marcus, 1867), 213; Peter Jessen, Das Ornament des Rococo (Leipzig: E.A. Seeman, 1894); August Schmarsow, Beiträge zur Ästhetik der Bildenden Künste. Barock und Rokoko (Leipzig: S. Hirzel, 1897). There were also many critics of the style, including: Gustav E. Pazaurek, Dreierlei Rokoko: Ausstellung im Königlich Württ. LandesGewerbemuseum Stuttgart 1909/Katalog im Auftrag der Königl. Zentralstelle für Gewerbe und Handel (Stuttgart: Klett \& Hartmann, 1909). See: Ireland, Cythera Regained, 118 and 158. Much 
Recent interest in applying transnational approaches to the study of art history has developed as a counterbalance to the focus in late nineteenth-century studies on the rise of the nation state; it has been set in the context of both traditional enquiries into internationalism and more recent interest in the importance of globalisation. ${ }^{6}$ As such, it has been argued, 'transnational history forms one of a series of terms which have been developed in order to help study engagement beyond the terms of state or nation-centred history, and especially so as to review, renew or go beyond comparative approaches. ${ }^{7}$ More specifically, a number of writers take this approach into the arena of cultural exchanges, the context in which the subject of this essay can be discussed. ${ }^{8}$ As stated by Michael Werner and Bénédicte Zimmerman, not 'all cultural differences map onto national differences: but where cultural differences do exist, they imply processes of acculturation, whose proper study requires that valorised notions of national cultural paradigms should be corrected by attentiveness to the particular economic, technological and human vehicles of cultural transfer.' 9 Thus, as much as it is important to analyse the ways in which the French style was appropriated in the writings of the period, it is also essential to discover the underlying mechanisms by which the style was accepted and promoted in Britain, and manifested by the continuing market for French decorative arts.

The motives for importing French taste into Britain can be examined fruitfully as part of a transnational and international phenomenon. While the English admiration for French things rarely progressed to an appreciation for

of this has to do with the revival of the style in both interiors and the decorative arts and as such is a different discussion from the present essay.

6 The literature concerning transnationalism as a conceptual framework mainly deals with twentieth-century or contemporary issues and the movement of people and ideas across borders. See: Stephen Vertovec, Transnationalism (Abingdon: Routledge, 2009).

7 Simon Macdonald, "Transnational History: A Review of Past and Present," January 2013, http://www.ucl.ac.uk/cth/objectives/simon_macdonald_tns_review.

8 Arjun Appadurai, Modernity at Large: Cultural Dimensions of Globalisation (Minneapolis: University of Minnesota Press, 1996) is cited as raising key issues explored within the framework of transnationalism. So is Christopher Alan Bayly, The Birth of the Modern World 17801914: Global Connections and Comparisons (Malden - Oxford: Blackwell, 2004). Bayly, when discussing the difficulties of using the term "transnationalism" wrote: 'At least in Europe, I get the sense that "trans-national history" stands in the same relationship to "international history" as "global history" does to "world history:" that it is much the same thing, except that the term "transnational" gives a sense of movement and interpenetration. It is broadly associated with the study of diasporas, social or political, which cross national boundaries, etc.' See: Christopher Alan Bayly et al., "AHR Conversation: On Transnational History," The American Historical Review 111, no. 5 (2006): 1441-64.

9 Macdonald, "Transnational History," 6. 
French painting, which remained under constant attack, imitating French interiors of the previous centuries was enormously in vogue: this arguably was not seen as "French" per se, but as a demonstration of wealth, taste and a reflection of the owner's position in society. The grandeur of the late nineteenth-century houses became a mark of the new wealth and prosperity of the country, and in this way they contributed to the national identity. Part of the context in which French works of art were collected and sold was thus the overall taste for the French style in decoration and architecture.

This essay therefore begins with an account of the market for French Ancien Régime furniture and then analyses the several factors underlying its continued success. It takes the well-known and highly visible collections of the nineteenth century, often described as opulent or ostentatious, and places them in a broader context, in which the French style emerges as part of British pride and appears as evidence of Britain's new role in world politics. The first part of this essay begins with the market, as it was the dispersal of goods after the French Revolution that made it possible for the British to collect on such a level. This democratisation of the market allowed anyone with money to aspire to what in the eighteenth century had been the preserve of the Prince of Wales and a small group of aristocrats and London elites. To understand the widespread acquisition and imitation of the French Ancien Régime style during the nineteenth century, we need to focus on the question of market demand. As such it is necessary to place it within the context of debates about British identity and to explore the various and often contradictory opinions given to this style. During the second half of the nineteenth century, discussion moved increasingly beyond the topos of magnificence. Played out in the battle of determining a style of decoration suitable to an increasingly prosperous and influential nation, arguments on improving British manufacture and British taste gained a moral force. Within the context of these debates, it will be argued that the concept of "cosmopolitanism" can help to understand how it was possible for a foreign style to be transformed into a signal of British wealth and success. ${ }^{10}$

10 The connections between internationalism, transnationalism and cosmopolitanism were brought out very clearly in the papers and discussions at a conference held at Tate Britain in 2013, organised by Grace Brockington and Sarah Victoria Turner, entitled Internationalism and the Arts: Imagining the Cosmopolis at the Long Fin de Siècle. As the authors state in their abstract, this conference 'adapted Benedict Anderson's theory of the nation as an imagined community in order to examine certain questions-about the locations, languages and citizens of an "imagined cosmopolis." They took up three themes, of place, language and cosmopolitanism, as they played out during an otherwise intense period of nation-building as part of their examination of cultural internationalism. The approaches taken by the speakers at the conference were instrumental in forming the arguments of this paper. 


\section{The Market for French Eighteenth-Century Furniture}

The taste in Britain for eighteenth-century French furniture from the Ancien Régime that developed during the nineteenth century followed many years of English aristocrats visiting Paris and purchasing luxury goods in the capital. Throughout the eighteenth century Paris had been the centre of civilised life for the British aristocracy. As many as 200 English visitors to Paris are recorded between 1739 and $1783 .{ }^{11}$ As the first stop of the Grand Tour, Paris was where young British aristocrats learned manners, how to converse and how to dress, and it was to Paris that British aristocrats, such as Horace Walpole, Lord Coventry in the 176 os or the young and Lord Spencer or the Duke of Bedford in the 1780 s, went to purchase furniture, porcelains, gilt bronzes and mirror glass. ${ }^{12}$ George IV, one of the most prolific purchasers of eighteenth-century French decorative arts, had been acquiring items and furnishing Carlton House as Prince of Wales in the latest Parisian taste before the Revolution. At Carlton House his patronage of the Francophile architect Henry Holland was extended to the French painter and decorator Jean-Jacques Boulieu (1787-1800) and to Dominique Daguerre (1772-96), one of the most important Parisian marchandmerciers who had migrated to London before the Revolution. Moreover, he bought, through Daguerre, furniture from contemporary Parisian cabinetmakers and also some earlier pieces. ${ }^{13}$ Most of the aristocratic purchases in Paris were of contemporary furniture, gilt bronzes and Sèvres porcelain; however, there is evidence that some collectors were buying Boulle furniture earlier in the eighteenth century. ${ }^{14}$ William Beckford, living in Paris, may have acquired

11 These would be mainly aristocrats either visiting Paris as part of their Grand Tour or occasionally going to Paris for shopping purposes. See: Robin Eagles, Francophilia in English Society (Basingstoke: Macmillan, 2000), 173-5.

12 For Horace Walpole's acquisitions of French ceramics, see: Sir Francis Watson, "Walpole and the Taste for French Porcelain," in Horace Walpole: Writer, Politician and Connoisseur, ed. Warren Hunting Smith (New Haven - London: Yale University Press, 1967), 185-94. For the 2nd Lord and Lady Spencer, see: Joseph Friedman, Spencer House: Chronicle of a Great London Mansion (London: Zwemmer, 1993); Christian Baulez, "Tout Europe tire ses bronzes de Paris," in Bernard Molitor, 1755-1833: ébéniste parisien d'origine luxembourgeoise, ed. Ulrich Leben (Ville de Luxembourg: Galerie d'art de la Ville de Luxembourg, Villa Vauban, 1995), 77-101. For accounts of shopping in Paris, see: Stella Tillyard, Aristocrats: Caroline, Emily, Louisa and Sarah Lennox, 1750-1832 (London: Chatto \& Windus, 1994).

13 Sir Geoffrey de Bellaigue, "George IV and French Furniture," Connoisseur 195 (1977): 116-25. This gives an account of George IV's purchases, including several from the dealer Dominique Daguerre for Carlton House bought before the revolution. See also: Sir Geoffrey de Bellaigue, "Daguerre and England," in Bernard Molitor, 157-79.

14 One recent example of a Boulle-piece acquired before the revolutionary sales has been discovered by Colin Demetrescu. See: Colin Demetrescu, "Le Cabinet de Boulle du duc de Buccleuch: une énigme Résolue," Dossier de l'Art no. 224 (2014): 30-59. 
his appreciation for the works of André Charles Boulle (1642-1732) from the extensive collections of rich French eighteenth-century financiers, such as Randon de Boisset (1708-76) or Augustin de Blondel de Gagny (1695-1776). The importance of Boulle furniture that dominated nineteenth-century collecting in Britain was thus predominantly a direct transfer of taste from the Parisian collector. ${ }^{15}$ Boulle furniture was one of the most highly desirable to collect, and thus this early appreciation of this work is one of the first examples of buying "antique" furniture made for a previous generation at a time when almost all furnishings would have been contemporary. The French Revolution and the number of works of art from royal and aristocratic collections to appear on the market have always been seen as key factors in the transformation of the market, not only in Britain, but perhaps more spectacularly there. It is worth mentioning that works of art from earlier periods were just beginning to appear in auction catalogues and references to certain types of historical pieces, such as Italian cabinets with panels of pietre dure, can be found listed in English sale catalogues from about $1800 .{ }^{16}$ Collecting French furniture from the eighteenth century was thus one of the several historicist movements that drew on the past to provide inspiration for the contemporary, ${ }^{17}$ but one with particular resonance and on a far larger scale, as the thousands of goods available created the perfect scenario for the English market, in which a burgeoning demand was fed and then multiplied by a plentiful supply.

Amongst the first to appreciate the possibilities of the market were the dealers. While it is very difficult to ascertain the exact mechanisms by which works of art were bought and sold, it seems that at the sales of royal furniture

15 Colin Bailey, "Conventions of the 18th-Century Cabinet de Tableaux: Blondel d'Azincourt, la premiere idée de la Curiosité," Art Bulletin 69 (1987): 431-7.

16 See: Clive Wainwright, The Romantic Interior (New Haven - London: Yale University Press, 1989), 1-53 for an introduction to the beginnings of historicist taste, collecting and dealers in Britain. William Beckford bought and created much furniture in a historicist style from the early years of the nineteenth century. See: Clive Wainwright, "William Beckford's Furniture," Connoisseur 191 (1976): 290-7; Adriana Turpin, "Filling the Void: The Development of Beckford's Taste and the Market in Furniture," in William Beckford 1760-1844: An Eye for the Magnificent, ed. Derek Ostergard (New Haven - London: Yale University Press, 2001), 177-202.

17 Rosanna Pavoni, ed., Reviving the Renaissance: The Use and Abuse of the Past in NineteenthCentury Italian Art and Decoration (Cambridge: Cambridge University Press, 1997). The introduction provides a strong argument that the revival of the Renaissance style was also seen by contemporaries as a form of improving the quality of design and manufacture. See for example: Annalisa Zanni, "The Neo-Renaissance as the Image of the Private," in Reviving the Renaissance, 29-47. 
in Paris held by the revolutionary government in the 179os the names of the buyers were all French. ${ }^{18}$ Many of them were dealers, but Jean-Henri Riesener (1734-1806), former cabinetmaker to Marie Antoinette, was also a buyer, acquiring at low prices the furniture he had supplied to the crown. ${ }^{19}$ How sales were then made to the English collectors, who had the money to buy, is not clear, but certainly English visitors flocked to Paris during the peace of Amiens between 1802 and 1803 . George IV certainly acquired a pair of cabinets at that time from Daguerre's partner, Martin-Eloy Lignereux (1751-1809) with plaques of pietre dure..$^{20}$ According to the royal accounts, many of George IV's acquisitions were actually made after 1815 and the opening up of the Paris market after the blockades of the Napoleonic Wars. ${ }^{21}$ However, it has always been suggested that some goods were allowed to leave France via Holland or Germany, so it is always possible that French furniture was available to collectors before $1815 .{ }^{22}$ Judging from the fact that so many works of art appeared in Britain after the defeat of Napoleon, it seems probable that they were bought during the revolutionary period by French dealers. A number of these had been successful auctioneers and dealers before the Revolution and were able to continue dealing in France under Napoleon. Alexander Pradère has shown how Lebrun, auctioneer of paintings before 1793, adviser to the French revolutionary government before 1803 and then dealer under Napoleon, both collected and

18 Michel Beurdeley, De Versailles à Paris: le destin des collections royales (Paris: Centre Culturel du Panthèon, 1989), 115-26 and La France à l'encan - Exode des objets d'art sous la Révolution (Fribourg: Office du Livre, 1981). For a partial account of the market during this period, see: Turpin, "Filling the Void." For a useful summary of the Parisian dealers and their activities in the first half of the nineteenth century, see: Sylvain Cordier, Bellangé ébénistes: une histoire du goût au XIXe siècle (Paris: Mare et Martin, 2012), 319-87.

19 Michel Beurdeley, "Ventes du mobilier royal de Versailles," in De Versailles à Paris: le destin des collections royales, $115^{-26}$.

20 Sir Geoffrey de Bellaigue, "Martin-Eloy Lignereux and England," Gazette des beaux-arts 71 (1968): 283-94.

21 Sir Hugh Roberts, For the King's Pleasure: The Furnishing and Decoration of George IV's Apartments at Windsor Castle (London: Royal Collections, 2001).

22 Charles Davillier, Vente du Mobilier du Château de Versailles pendant le Terreur (Paris: August Aubry, 1877). Davillier quotes a newspaper advertisement in Haarlem 1794 for the sale of French royal works of art. Although it is not certain, the sale probably took place in Holland and not in Paris. See also: Pierre Verlet, "Chapeaurouge et les collections royales françaises," in Festschrift für Erich Meyer zum 6o. Geburtstag, 29. Oktober, 1957: Studien zu Werken in den Sammlungen des Museums für Kunst und Gewerbe, Hamburg, ed. Werner Gramberg (Hamburg: Hauswedell, 1959), 286-94. 
sold Boulle furniture, some even to Napoleon. ${ }^{23}$ The leading Parisian dealers, amongst whom Philippe-Claude Maëlrondt (1766-1824) was perhaps the most famous, sold French Ancien Régime furniture to the English and, once established, the collecting of French works of art only intensified in the years after the end of the Napoleonic Wars. ${ }^{24}$ Not only did Maëlrondt gather works of art in Paris that would appeal to the English taste, he worked with cabinetmakers such as the Bellangé family to supply old and new furniture to an extensive list of clients, most notably George IV and often through English intermediaries. ${ }^{25}$

Although French dealers may have dominated the supply to England in the early years of the nineteenth century, soon afterwards, English dealers began to buy directly in Paris and import French works of art into the country. By 1845 when the auction house of Foster and Son put up for sale 'FOREIGN ANCIENT ELEGANCIES including beautiful marqueterie commodes, consoles and tables,' the catalogue went on to say 'which by direction of the IMPORTER will be sold by auction.' Sir Geoffrey de Bellaigue has traced the career of one of the most significant of these dealers and importers, Edward Holmes Baldock, itemising his sales of Sèvres porcelain and eighteenth-century French furniture to such distinguished collectors as the Duke of Buccleuch and Queensberry, where surviving bills show the extent of the purchases and the sums paid to Baldock (Fig. 7.1). ${ }^{26}$ It seems that Baldock bought his works

23 Alexandre Pradère, "Lerouge, Le Brun, Bonnemaison: The Role of Art Dealers in the Commerce of Boulle Furniture from the Revolution to the Restoration," Revue de l'Art no. 184 (2014): 47-62.

24 Catalogue d'objets rares et curieux, composant le fonds de commerce De Feu M Maëlrondt (Paris: M. Pérignon, 1824). Maëlrondt's sale catalogue of 15 November 1824 lists some 40 examples of French cabinet-work (lots 306-46) as well as mirrors and clocks, porcelains, paintings and sculptures. The sale took place after his death and was presumably a clearing of his stock.

25 Bills show that one of the king's dealers, Robert Fogg, bought extensively from Maëlrondt. See: Carlton House: The Past Glories of George IV's Palace (London: The Queen's Gallery Buckingham Palace, 1991), 80. There is a complete listing of furniture acquired for Windsor in: Sir Geoffrey de Bellaigue, "Phillippe-Claude Maëlrondt, Supplier to George IV," Burlington Magazine 146 (2004): 386-95. See also: Cordier, Bellangé ébénistes, 319-87.

26 Buccleuch archives, Drumlanrig Castle. There are bills from 1836 to 1848 itemising works of art supplied to Walter Francis, 5th Duke of Buccleuch and Queensberry, including many items of French furniture. For a further analysis of the bills, see: Sir Geoffrey de Bellaigue, "Edward Holmes Baldock I," Connoisseur 189 (1975): 290-9; and Id., "Edward Holmes Baldock II," Connoisseur 190 (1975): 18-25. Copies of the bills are also held at Boughton House and I am most grateful to Crispin Powell for his help in studying them and kindly photograph one for me. Also my grateful thanks to the Duke of Buccleuch and Queensberry for allowing me access to the archives and permission to photograph them. 


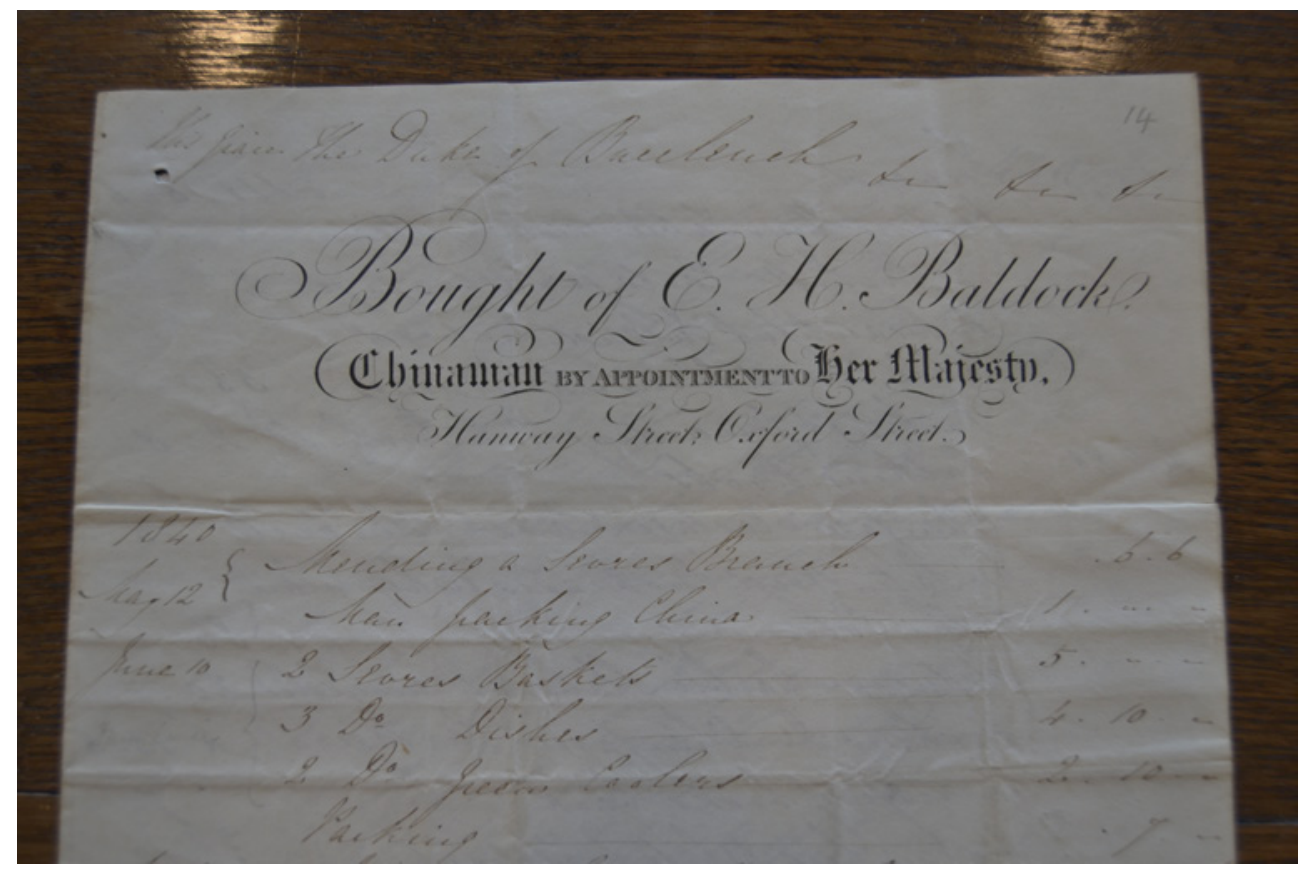

FIGURE 7.1 Heading of bill from Edward Holmes Baldock to Walter Francis, 5th Duke of Buccleuch, 1840. Thornhill, Buccleuch Archives

(C) COURTESY OF THE DUKE OF BUCCLEUCH AND QUEENSBERRY

of art in Paris, although his name also appears on English auction catalogues. Baldock, of course, not only bought pieces of Sèvres or important examples of French furniture which he brought into England; he also bought parts of old furniture and remade them into new pieces or had the Sèvres porcelain mounted or re-mounted for the English market. His sale catalogue of 1843 , for example, has several lots of ebony panels, which he no doubt used to create cabinets or cupboards in the style of the French seventeenth century. ${ }^{27}$

The market for furniture from the Ancien Régime was thus created primarily in England firstly by French and then English dealers. In France, at least in the first part of the century, modern furnishings seem to have been more

$27 \quad$ William Beckford made a great cabinet with ebony panelled doors of which he was very proud. He used recycled seventeenth-century panels and in turn, when his cabinet was sold in 1823 , it was bought by Baldock for $£_{572} 6$ s and dismantled. The doors were sold after Baldock's death in the sale of 21 July 1843 and bought by de Sommarard. Several cabinets of this type are in the Musée de la Renaissance, Écouen. See: De Bellaigue, "Edward Holmes Baldock II," 21; and Turpin, "Filling the Void," 200. 
appreciated than antiques. For example, the price of $45^{\circ}$ francs realised for a Boulle cabinet by the dealer Rocheux to the garde-meuble for Fontainebleau in 1807 is remarkably low in comparison to 3,000 francs for a new mahogany secretaire. ${ }^{28}$ In England, however, as evidenced through the sales taking place throughout the century, there was a strong and continuous market for antique French furniture, which were highlighted by the dealers and auctioneers, even though of course modern copies and pastiches were also sold throughout the century. The first sale catalogues selected two main criteria to highlight the importance of their sales: royal provenance and the historic names of André Charles Boulle and Riesener. The first sale catalogues emphasised that the works of art came directly from Paris; that they were often described as royal added to their authority. This was clearly stated on the front pages of the catalogues. An 1816 Phillips sale catalogue, for example, was presented as a Catalogue of Parisian furniture including 4 armoires, 3 splendid commodes, cabinets etc [...] from the Palaces of Versailles and Compiegne and the Chateau of Malmaison or in 1818, a Catalogue of one of the most splendid and extensive selection of Parisian Furniture, Bronzes etc that has ever been imported $[. . .]^{29}$

Moreover, the catalogue entries and the prices fetched clearly highlight the importance of furniture by André Charles Boulle and Jean-Henri Riesener. The name of Boulle is not surprising in that French collectors throughout the eighteenth century had paid great sums for his work. That of Riesener was a new phenomenon, possibly a direct result of its availability on the market and the dealers' promotion of him as the 'royal cabinetmaker' to Louis XVI and his queen. At the sale of Wanstead House in 1823, a Parisian Boulle cabinet in brass and tortoiseshell described as antique reached $£_{31} 10 s$ and a superb Parisian Boulle commode in the Grand Salon went for 40 guineas or $£ 446 s$, both amongst the highest prices paid for individual pieces. ${ }^{30} \mathrm{~A}$ few years later at the sale held by 'A Gentleman from the West Country', thought to include furniture owned by William Beckford, a Boulle writing table was sold for a similar amount, £25 4s; however a red Boulle armoire said to have been made for Louis XV's cabinet at Versailles fetched much more at $£_{23} 65$ s, which reflects the emphasis placed on authenticity and provenance. ${ }^{31}$ Similar huge prices were

28 Cordier, Bellangé ébénistes, 320.

29 The Wallace Collection Library: Phillips SAL1816 and Phillips SAL1818.

$30 \quad$ Lot 26, from the Grand Salon, Wanstead House, 1823, 203.

31 Lot 167, Sale of furniture of Gentleman from the West of England, Phillips, 22 June 1825. The website Measuringworth.com provides four ways to view historical prices in current terms. One ('real price') is based on calculating inflation as cost of a typical bundle of goods and services consumed by an average worker, thus, the increase in the UK retail price index ('RPI'). The second ('labour value') calculates the cost in terms of the same 
reached for exceptional pieces of Boulle in the two important sales by George Watson-Taylor. ${ }^{32}$ Furniture by Riesener could reach equal heights. Thus in the same sale of 1825 , the Marquess of Hertford paid $£_{179} 11 s$ for a Riesener rolltop desk, described as coming from the French royal garde-meuble. ${ }^{33}$ The sale contained a lacquer commode, which fetched a not dissimilar price of $£ 10712 \mathrm{~s}$ without the Riesener name, perhaps because of the fine lacquer. ${ }^{34}$ George IV most famously paid the highest price reached at the time for a piece of French furniture, £420, with the purchase of the cabinet made for the Comtesse de Provence at the 1825 sale of George Watson Taylor's collection (Fig. 7.2). The description below of one of the most important and most expensive pieces of French furniture brings together the various selling points emphasised to attract the wealthy buyer:

proportion of typical worker's wages. This normally gives a higher figure due to the real increases in wages over time. The authors of the website add two additional ways to determine value: 'income value' takes into account salaries, investment and cost of services which have normally exceeded wage increases, and 'economic share,' which refers to economic power (the relative power the purchaser would have in controlling production within the economy). For example the $1825 £ 2365^{\mathrm{s}}$ quoted would be the equivalent in 2017 of £18,430 in real terms, £193,00o in terms of labour value, £243,100 when measured by income value and $£ 968,600$ when measured by its economic share. https:// www.measuringworth.com, accessed 10 November 2018.

George Watson Taylor (1771-1841), a Jamaica sugar merchant, Member of Parliament and one of the most lavish collectors of French decorative arts, put together a collection of art that, when it was sold, set the standard and prices for French decorative arts that lasted throughout the century. There were two sales. One from his London town house in Cavendish Square, sold at Christie's, 28 May 1825, see: Catalogue of a Selection of Sumptuous Articles of Parisian and other Furniture, [...] some [...] Groups and Busts of Bronze, and Various Sculpture, from the [...] Mansion of G.W. Taylor [...] Which will be sold by auction, etc. (With Notes and Prices). The second was the sale from his country house at Erlestoke Manor in 1832, see: Catalogue of the Magnificent Assemblage of Property at Erlestoke Mansion near Devizes [...] accumulated [...] by G.W. Taylor [...] which will be Sold by Auction, by Mr. George Robins [...] the gth Day of July, 1832, and Twenty Succeeding Days, etc.

33 Lot 282 , a 'secretaire elaborately inlaid by Riesener in fanciful design sumptuously mounted and enriched in highly chased gilt-bronze mounts [...] the interior fitted with a great variety of secret and other drawers, the whole finished and executed with that degree of elaborate care, for which the Artist was justly celebrated.' Phillips, 22 June 1825. This was the desk now known to have been made for the Comte d'Orsay at the Wallace Collection. See: Peter Hughes, The Wallace Collection Catalogue of Furniture, vol. 2 (London: Trustees of the Wallace Collection, 1996), 939-40.

34 Lot 168, 'a saloon commode of ebony and panelled with specimens of the finest old Japan, angles formed by antique trusses [...] gilt ormolu, solid slab of Italian marble.' Phillips, 22 June 1825 . 


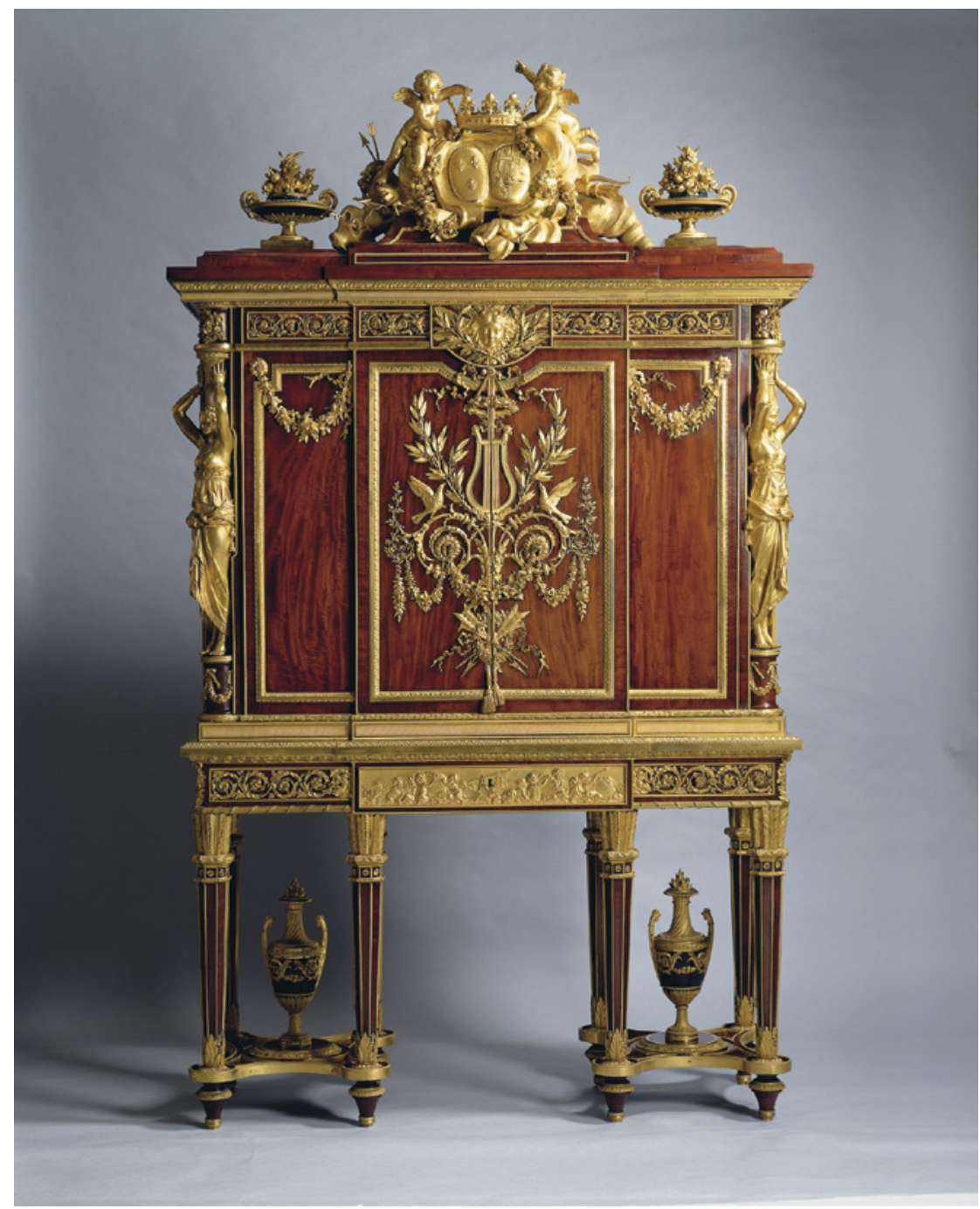

FIGURE 7.2 Jean-Henri Riesener, Jewel cabinet made for the Comtesse de Provence, 1774. Mahogany veneer with gilt-bronze mounts, $246 \times 147 \times 54.6 \mathrm{~cm}$. Windsor, Royal Collection Trust

(C) HER MAJESTY QUEEN ELIZABETH II 2018

A MAGNIFICENT CABINET of mahogany elegantly disposed in three panels or compartments, opens by folding doors, surmounted by a mask of Apollo, and a frieze of foliage. In the centre panel is suspended the lyre of Apollo between two wreaths of olive, resting upon a torch which springs from the centre of two branches with Arabesque scrolls connected 
by festoons [...] The arms of a branch of the royal family of France and a group of Cupids of or-molu surmount this splendid piece of furniture (a chef d'œuvre of the ingenious Riesner) [...] and formerly belonged to the Palace of Versailles where it was sold by the commissioners of the French Convention in an early period of the Republic. ${ }^{35}$

Even taking into account the hyperbole of the auction houses, the language of the sale catalogues emphasised the status of French furniture as a collectable commodity and it is clear that what was being sold was status. 'A matchless Louis XIV Boule table,' 'a superb Parisian commode,' 'a noble and lofty armoire:' these were the terms in which this furniture was described.

Thus by the 1830 s the prices and reputation of French eighteenth-century furniture was well established and the names of Boulle and Riesener recognised both for the quality of the work and the reputation of the cabinetmakers. In sales later in the century, French furniture continued to command enormous prices, amongst them the sales of the entire contents of Stowe in 1848 and the Hamilton Palace sale in 1882. They are reflections of the extensive amassing of great collections of French furniture, many of which still survive today in the Wallace Collection, at Waddesdon Manor (Rothschild) or Dalmeny (the Earl of Rosebery), to name only some of the most extensive. The acquisitions by the wealthiest collectors in Britain provide a testament to the enormous importance of owning French works of art during the century, which only diminished when wealthier collectors, most notably from the United States, could afford to pay sums of money that their European counterparts found hard to match. ${ }^{36}$ As has often been pointed out, the furniture at the Hamilton Palace sale in 1882 eclipsed the prices paid for paintings or any other type of artwork. The names of Boulle and Riesener still carried enormous weight; some of the documented pieces by Riesener fetched nearly ten times that of an unsigned piece. ${ }^{37}$ The Boulle cabinets inherited from Beckford and bought at $£_{400}$ were

35 Sale of the contents of Cavendish St. Watson Taylor, Christie's, 28 May 1825, lot 76.

36 The story of the acquisition of French furnishing by the leading collectors in the United States, including Mr. and Mrs. William Vanderbilt, whose collections were donated to the Metropolitan Museum, and Henry Clay Frick, who created his own museum in New York, to mention only some of the earliest buyers of French furniture, is well documented, most recently by Christopher Maxwell, "The Dispersal of the Hamilton Palace Collection," (PhD diss., University of Glasgow, 2014). I am hugely grateful to Kit Maxwell for sharing his unpublished thesis with me.

37 Lot 293, 'a cabinet, the frame of mahogany with panels of gold Japan lacquer with richlychased metal-gilt mounts by Auguste [...] sold for $£ 493$ 10s; lot 300, a Louis XVI secretaire made for Madame du Barry, sold for $£_{43}$ 1os. The Hamilton Palace Collection, Illustrated Priced Catalogue (Paris - London: Christie's, 1882), 42-3. 
sold for $£ 12,075$; a Riesener commode fetched $£ 4,305$, while the lacquer-veneered secretaire and commode supplied to Marie Antoinette by Riesener were sold for a total of $£ 19,000 .^{38}$

The collecting of French furnishing was not, however, just confined to the aristocracy or the opulent millionaires, who, as will be seen, decorated their London houses with choice specimens of French furniture. There was a steady and increasing market for French furniture at every level. The Foster auction catalogues held at the Victoria and Albert Museum show that in the biweekly sales held in their auction rooms in Greek Street, Soho, furniture in the "old French" style abounded. As with the more important sales, furniture by Boulle and Riesener was marked out for mention. Generally called 'Buhl,' it was often not specified whether the object was authentic or an imitation of French work; the prices could be as low as $11 s$ or as high as several pounds. Those items described as Louis XIV, such as, for example, 'A Louis XIV Marqueterie commode of 4 drawers, with swept front, massively mounted, with or-molu handles, corners \& feet and Italian marble slab' was sold for four times that price. Thus the above lot sold at Fosters in 1845 fetched $£_{5} 17 s^{39}$ This is one indication amongst many that the auctioneers could differentiate between the old and the modern, but both were desirable.

The market for furniture in the French style remained strong throughout the last half of the century and 'old porcelain' and 'old decorative furniture' is found consistently in the drawing rooms of the London wealthy, sometimes cited as the property of 'a gentleman' and occasionally of 'a lady, sometimes the sales of individual collectors. ${ }^{40}$ Drawing on the Christie's catalogues of this period, it is clear that French furniture was found throughout the house, sometimes on its own but equally it could be combined with furniture from other

38 The Boulle cabinet (lot 672) was sold to S. Wertheimer; the Riesener commode (lot 302) was sold to H. Stettiner; the lacquer secretaire and commode were sold to S. Wertheimer. The Hamilton Palace Catalogue, 42, 88 and 163 .

39 National Art Library, London: FOREIGN ANCIENT ELEGANCIES including beautiful marqueterie commodes, consoles and tables ... French Secretaires, Suites of Tapestry from the looms of Beauvais \& Gobelins ... A suite of Boule commodes, Bibliotheques, Library \& other tables for a drawing room richly decorated with or-molu and about two hundred cabriole chairs in sets of six, twelve and twenty-four which by direction of the IMPORTER will be sold by Auction by Messrs Foster and Son at the Gallery 54 Pall Mall on Thursday the 15 th of May, 1845 and two following days.

40 There is a great deal of research that still needs to be done in the sale catalogues to identify the extent of the market for French works of art. Just a short survey of later sales at Christie's, citing collections of lesser-known collectors such as Christopher Dennison, shows the extent to which French furniture, bronzes and Sèvres porcelain were collected in London. 
countries, often Italy. Thus in the sale of Christopher Beckett Denison Esq. at Christie's in 1885, alongside the large collections of French and German porcelain, Wedgwood, French clocks, English and decorative furniture, there was a section of 'Old French Decorative Furniture' with obviously original works. Amongst these was a Louis XVI mahogany cabinet, richly mounted, from the Alexander Barker sale, fetching $£_{135}$. All of the other commodes, cabinets or desks described as Louis XV or Louis XVI were sold for much less, between $£_{25}$ and $£_{35}$ on average, while a modern upright satinwood cabinet sold for $£ 610{ }^{41}{ }^{41}$ Denison clearly had a strong collection of French furniture, with only some modern pieces or from other countries. The sale of an anonymous collector, 'A Gentleman from the Country,' which took place in 1875, also shows that prices could be very high for Louis XVI furniture, with some of his furniture reaching $£_{136} 10 s$ for a Louis XVI commode of 'old marquetry' or $£_{535} 10 s$ for two Louis XVI parqueterie cabinets in rosewood. ${ }^{42}$ The most expensive piece, a Louis XVI escritoire in tulipwood, was sold to the dealer in French furniture, Durlacher, for $£_{276} 6^{43}$ With such widespread interest in French furnishing it is not surprising that the market remained so strong. The question thus remains as to why collectors were motivated to spend such sums at the top end of the market as well as why the taste for a French-based decorative style remained so appealing to the British of all types of wealth and backgrounds throughout the nineteenth century.

\section{From Criticism to Appreciation}

The admirers of original French works of art might cite the great skill, ingenuity and beauty of the originals to defend furnishing their houses and collecting such pieces. However, this admiration needs to be set in the context of a long tradition of distaste and distinct antipathy from British critics often couched in nationalistic terms: the decadence of French art was contrasted with the pure, simple style associated with England. French art was thus seen as 'weak,

\footnotetext{
41 Lot 3276, Second Portion of the Valuable Collection of Pictures, Works of Art and Decorative Objects of Christopher Beckett Denison, Esq. Christie's, Manson \& Woods, 25 June 1885.

42 Lots 154, 158 and 159, Catalogue of the Very Choice Collection of Old Porcelain and Decorative Furniture, the Property of a Gentleman received from a Mansion in the Country, Christie's, Manson and Woods, 3 June 1875.

43 Id., Lot 276. Durlacher Brothers was established in 1843 and counted amongst its clients J. Pierpont Morgan and Sir Richard Wallace. They also advised the Victoria and Albert Museum on their acquisitions. See: http://www.vam.ac.uk/content/articles/d/ durlacher-brothers/.
} 
ill-jointed and unmeaning' as well as representing — at least in the eighteenth century - the worst kind of government. In 1753 Isaac Ware wrote: 'Let us rouse in every sense the national spirit then; and no more permit them to deprave our taste in this noble science than to introduce among us the miseries of their government or fooleries of their religion. ${ }^{44}$ It was, of course, the rococo style that drew most criticism, particularly after it had fallen from favour throughout Europe. As a result Joshua Reynolds accused French painters, even Poussin and seemingly Boucher, as corrupting 'the true taste and leading it astray from the pure, the simple and grand style by a mock majesty and false magnificence. 45

Throughout the nineteenth century, the same arguments were presented in the journals. British nationalism often expressed itself as anti-French, and critics explained that British painting exemplified British virtues, such as domesticity, simplicity, love of the countryside and morality, in contrast to the excesses of French art. Robert Buchanan, in his attack on Swinburne's poetry, placed the source of corruption in France: 'All that is worst in Mr. Swinburne belongs to Baudelaire. The offensive choice of subject, the obtrusion of unnatural passion, the blasphemy, the wretched animalism, are all taken intact out of Les Fleurs de Mal.46 This is not to say that certain French artists such as Delacroix and Ary Scheffer (who was Dutch by birth) were not admired; however, it has been argued that Scheffer's popularity in England stemmed from his religious morality and thus, in effect, he retained the high moral values associated with British painters. He was collected both by the liberal political families and Liverpool and Manchester merchants.

Criticisms of the French style in architecture stressed the vulgarity of French interiors, implying again a lack of morality. Thus, when writing about the rebuilding of Buckingham House, Johann David Passavant (1787-1861), visiting London in 1836 , commented: 'everyone will join in regretting that so much money should have been expended in converting a fine old palace into one, which from the insignificance of its proportions and unimposing exterior does little credit to the taste of the English nation. ${ }^{47}$ The explanation he gave was

44 Isaac Ware, A Complete Body of Architecture (London: T. Osborne, J. Shipton; etc., 1768). Quoted in: Edward Morris, French Art in Nineteenth-Century Britain (New Haven London: Yale University Press, 2005), 5-6.

45 Henry W. Beechey, "Introduction," in Id., The History Works of Sir Joshua Reynolds, to which is prefixed a Memoir of the Artist by Henry W. Beechey, vol. 1 (London and Edinburgh: T. Codell, Strand and W. Blackwood, 1835), 97. The memoir is based on: James Northcote, Life of Sir Joshua Reynolds Comprised of Original Anecdotes ... and a Brief Analysis of his Discourses, vol. 1 (London: Colborn, 1818), 56 .

46 Morris, French Art in Nineteenth-Century Britain, 178-80.

47 Johann David Passavant, Tour of a German Artist in England, With Notices of Private Galleries, and Remarks on the State of Art (London: Saunders and Ottley, 1836), 119. 
that the magnificence of the interiors satisfied the demand of the new king for an opulent and rich setting for his palace. Passavant continued his disapproval of the style.

It is owing to this, viz. that whatever is most rich is most desirable, that we find the English in their gilt balustrades, chandeliers, brackets \& so closely imitating the taste of Louis XIV, in whose reign this mannered style of ornament was most in vogue; and even furniture of this kind, inlaid with a profusion of tortoiseshell, or brass, and groaning beneath the weight of numberless little knickknacks, no less grotesque than itself, is everywhere to be met with in the houses of the wealthy.48

Such criticisms from the early part of the century were repeated even more frequently later in the century. Influential writers, such as Charles Locke Eastlake in his Hints on Household Taste, published in 1869, or Edith Wharton in The Decoration of Houses, published some thirty years later, condemned the excesses of French ornamentation or gilding found in contemporary furniture and decoration. ${ }^{49}$ As stated in his introduction, Eastlake's purpose was to improve contemporary design by showing how design should follow function. He argued for chaste and sober forms, 'never running into extravagant contour or unnecessary curves. ${ }^{50}$ French furniture was the opposite of this notion. Thus, he argued, 'that school of decorative art, bad and vicious in principle as it was, had a certain air of luxury and grandeur about it which was due to elaboration of detail and richness of material. Its worst characteristic was an extravagance of contour and this is just the only characteristic which the tradition of upholstery has preserved. ${ }^{51}$ Other writers went further in their attack on this foreign style, as in The Lady in 1897, when J.H. Duncan wrote: 'We have so many beautiful styles of our own that it is sheer perversity that prompts us to adopt styles of foreign importation, for which we have no continuity of tradition. ${ }^{.52}$

48 Passavant, Tour of a German Artist, 140.

49 Charles Locke Eastlake, Hints on Household Taste in Furniture, Upholstery and Other Details (London: Longman, Green \& Co, 1869). As he states, the series of essays had been produced for Cornhill Magazine and the London Review and was aimed to address the question of style and design in contemporary manufacture. Edith Wharton and Ogden Jr. Codman, The Decoration of Houses (London: Batsford, 1898).

$50 \quad I d ., 143$.

$5^{1} \quad I d ., 55^{-6 .}$

52 John Hudson Elder Duncan, The Lady 26 (1897): 798, quoted in: Cooper, The Opulent Eye, 17 . 
Gradually critics began to find elements of French design they approved of. Marshall's French Home Life, originally published in Blackwood's Journal and then republished as a treatise in 1873 , presented a synthesis of how French design could be given moral value. ${ }^{53}$ For Marshall bad design and taste had moral implications, which were linked to society's political and social policies. In discussing the role of the contemporary French servant, which begins the book, Marshall credits the French Revolution as having levelled classes and raised 'the moral and political value of each individual affected by it. ${ }^{\text {'4 }}$ He blames French design for a decline in taste and its replacement by a desire for ostentation, show and also an excessive interest in comfort. ${ }^{55} \mathrm{He}$ was, of course, discussing the France of the Second Empire and the problems of revivals rather than the originals from the eighteenth century. Further on, he argues that it was contemporary furniture, not antique, that had lapsed into this bad taste; thus he leaves open the possibility that original eighteenth-century furnishings might avoid such grave condemnation.

Writing on the need to reform contemporary decoration, Edith Wharton also tackled the question of taste, arguing that what was satisfactory depended on the appropriate relationship between the object and the interior. ${ }^{56}$ In her attempt to reform the interior from the excesses of historic revivals, she brought a different approach from those who, like Passavant, only saw excessive ornamentation in French furnishings. She could be forgiving of French design, but only when used as originally intended: 'when the rocaille manner was at its height, the main lines of a room were seldom allowed to follow the capricious movement of the ornamental accessories. ${ }^{57}$ As long as the individual piece of furniture was subordinate to the overall decoration of the room, for Wharton the style could indeed be French. In her attempt to reform the decoration of the contemporary interior, she therefore emphasised a new understanding of good taste: that each piece placed in an interior should be considered in relation to its importance to the room as a whole.

Frederic Marshall, French Home Life (Edinburgh - London: William Blackwood and Sons, 1873). Blackwood's was a popular magazine with an extensive readership.

$54 \quad I d ., 10$.

$55 \quad$ Id., 90.

56 Wharton and Codman, The Decoration of Houses, 85 .

$57 \quad$ Id., 56 . 


\section{Wealth and Ostentation}

In spite of the condemnation from critics, the French style was found in the drawing rooms of both town and country houses. Hermann von PücklerMuskau, writing in 1831, offered one very plausible reason for the success of the French style in Britain, namely that it was 'very consistent in a country where the nobility grows more and more like that of the time of Louis the Fourteenth. ${ }^{18}$ One motive would seem to be that British aristocrats adopted the French style as appropriate to their new status as victors of the Napoleonic Wars, and thus that they were the inheritors of the grandeur of eighteenthcentury France. By the 1820s George IV, the creator of Windsor, could be said to have absorbed and taken over French decoration-despite having been an ardent supporter of the early stages of the Revolution as a young man-installing it within the Gothic exterior of the castle, thus making it "English." It may have been the patronage of George IV that prevented the French style from acquiring the political overtones in the nineteenth century that it had during the eighteenth century. The 5th Duke of Buccleuch, who recreated Montagu House in the 1850 s with drawing rooms decorated in the rococo style featuring fine examples of eighteenth-century cabinet work and carving, was a Tory peer, as was Lord de Grey, who built Wrest Park in a similar fashion. However, aristocrats with very different political views - such as the Devonshires and other Liberals - could also espouse this style in order to display the benefits of British prosperity, the results of industry and trade. Thus the ostentation implicit in the style became a virtue; the change from previous criticism was that now the French style was seen as combining skill and excellence of craftsmanship, and thus, in its original form, it could be admired. This may be one reason why late nineteenth-century fashion concerned itself with the much closer imitation of the eighteenth century rather than the early years of the century.

The most obvious characteristic of the revived French style was its luxury, exemplified by its gilded and elaborate decoration. As has been seen this was both the most common criticism of the Ancien Régime interior, but it was also an essential part of its appeal. By the 1840 s this form of decoration had become established as the accepted interior of the aristocracy. It is against this architectural revival that the taste for collecting original French furnishings must be briefly discussed. Combining architectural designs from the seventeenth to the late eighteenth century, this hybrid and eclectic revival, sometimes

$5^{8}$ Hermann von Puckler-Muskau, Tour in England, Ireland, and France, in the Years 1828, and 1829. [...] In a Series of Letters. By a German Prince, transl. Sarah Austin, vol. 4 (London: Carey, Lee and Blanchard, 1832), 338-9. 
called the 'Tous les Louis'-style or 'old French style'59 appeared in the great London mansions and palaces, establishing it as an accepted decoration for the richest members of the aristocracy. One of the first examples was created for the Duchess of Rutland by Benjamin Dean Wyatt and Matthew Cotes Wyatt at Belvoir Castle. Using panelling from eighteenth-century Parisian salons, the architects created a reception room for the duchess combining the antique panels with modern interpretations of a ceiling from Louis XIV's Versailles. ${ }^{60}$ Benjamin Wyatt went on to work for the Duke of York for his new house in St. James's Park (now Lancaster House), which was then taken over and finished by the richest peer of his generation, George Granville Leveson-Gower, Marquess of Stafford and later ist Duke of Sutherland (1758-1833), ${ }^{61}$ while his brother, Philip, created equally splendid interiors for the Marquess of Londonderry at Wynyard Park (1822-8) at a cost of £102,097 12s od. ${ }^{62}$ When George IV had the state rooms of Windsor redecorated by his architect, another member of the Wyatt family, Sir Jeffry Wyatville, added the seal of royal patronage of the style.

An early collector of French furniture, George IV, passionate in his interest in French politics and art, was certainly one of the most influential in the drive to display antique furniture in his newly decorated, grandiose interiors (Fig. 7.3). From a young man and throughout his life, he expended huge sums on French porcelain and furniture from the eighteenth century and his purchases of French works of art, set in the newly created rooms at Windsor Castle or Buckingham Palace, created a standard that continued until the end of the century. Ferdinand de Rothschild, for example, stated in his memoires that he modelled himself on George IV and William Beckford. ${ }^{63}$ William Beckford (1760-1844) also had strong links to Paris before the Revolution. One of the most notable collectors of the early nineteenth century and considered one of the chief arbiters of taste in his lifetime, he had lived in Paris until the

59 See the designs published by George Smith (1786-1828) especially in his Cabinet-Maker and Upholsterer's Guide (London: Jones \& Company, 1826) or in Henry and Aaron Arrowsmith, The House Decorator and Painter's Guide (London: Thomas Kelly, 1840).

$60 \quad$ John Martin Robinson, The Wyatts: An Architectural Dynasty (Oxford: Oxford University Press, 1979).

61 James Yorke, Lancaster House: London's Greatest Town House (London: Merrell, 2001).

62 Robinson, The Wyatts, 121. To place this in context, the equivalent for the project in 2018 terms would be $£ 9,074,000$ in real terms, $£ 90,390$, ooo in terms of labour cost. The economic cost of the project has been estimated at $£_{520,100,000}$. See footnote 31 . Figures taken from Measuringworth.com, accessed 30 March 2018.

63 Ferdinand de Rothschild, "The Expansion of Art," in The Fortnightly Review, ed. Thomas Hay Sweet Escott (London: Chapman and Hall, 1885), 55-69, quoted in: Michael Hall, Waddesdon Manor: The Heritage of a Rothschild House (New York: Harry Abrams, 2002), 100. 


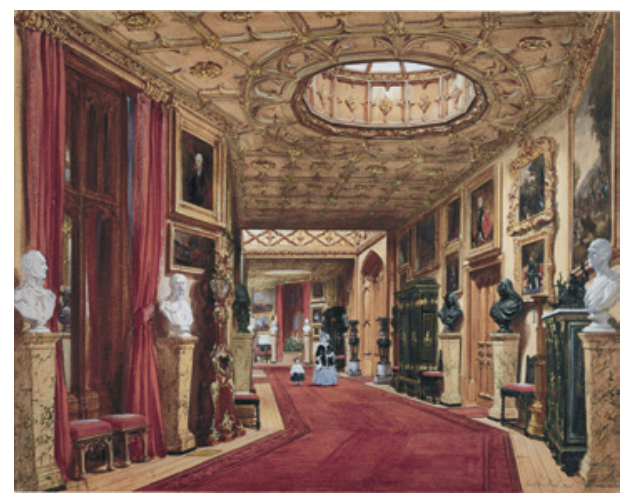

FIGURE 7.3

Joseph Nash, Windsor Castle: the angle of the grand corridor, showing Boulle furniture and a clock by Charles Cressent, 1846. Watercolour and bodycolour over pencil, $33 \times 41.5 \mathrm{~cm}$. Windsor, Royal Collection Trust (C) HER MAJESTY QUEEN ELIZABETH II 2018

outbreak of the Revolution. ${ }^{64}$ George Watson Taylor, a newly rich Jamaica sugar merchant, furnished his two homes with the finest examples of French furniture. The extravagant lifestyle and spending of his wife's fortune by PoleTylney-Long-Wellesley, nephew to the Marquess of Wellesley, led to the sale of Wanstead House in 1823. The Watson Taylor and Wanstead House sales were important because they give evidence to the major role French furniture had in the decoration of grand London and country houses early in the century, when they were particularly associated with the furnishing of the principal state rooms, such as the state drawing room, the grand saloon or other such rooms intended for entertainment and display.

As the century progressed, emulation by the new wealthy-the new plutocrats of whom there were certainly an enormous number-was also a form of overtaking and outdoing Ancien Régime prototypes and possibly even the aristocrats from whom so many bought houses. The decoration and furnishing of these houses thus came to be associated with general ideas of aristocratic splendour, as it was suitable for entertaining and for the lavish parties given in these houses (Fig. 7.4). As Passavant remarked about Gower House: 'There is something in these wreaths of curling leaves and twisted ends, especially when covered with the most gorgeous gilding, which attracts the eye more than the simple forms of pure taste. ${ }^{65}$ Visitors all cite opulence and ostentatious display as the key features of these interiors, noting that they were finer than the original French models. Henri Bischoffsheim's palace in Mayfair, previously the home of Lord Bute (an eighteenth-century aristocratic family), was described by contemporaries as a Versailles in miniature. The interiors of

64 Anne Eschapasse, "William Beckford in Paris, 1788-1814: 'Le Feste Solitaire," in William Beckford 1760-1844, 199-216.

65 Passavant, Tour of a German Artist, 140. 


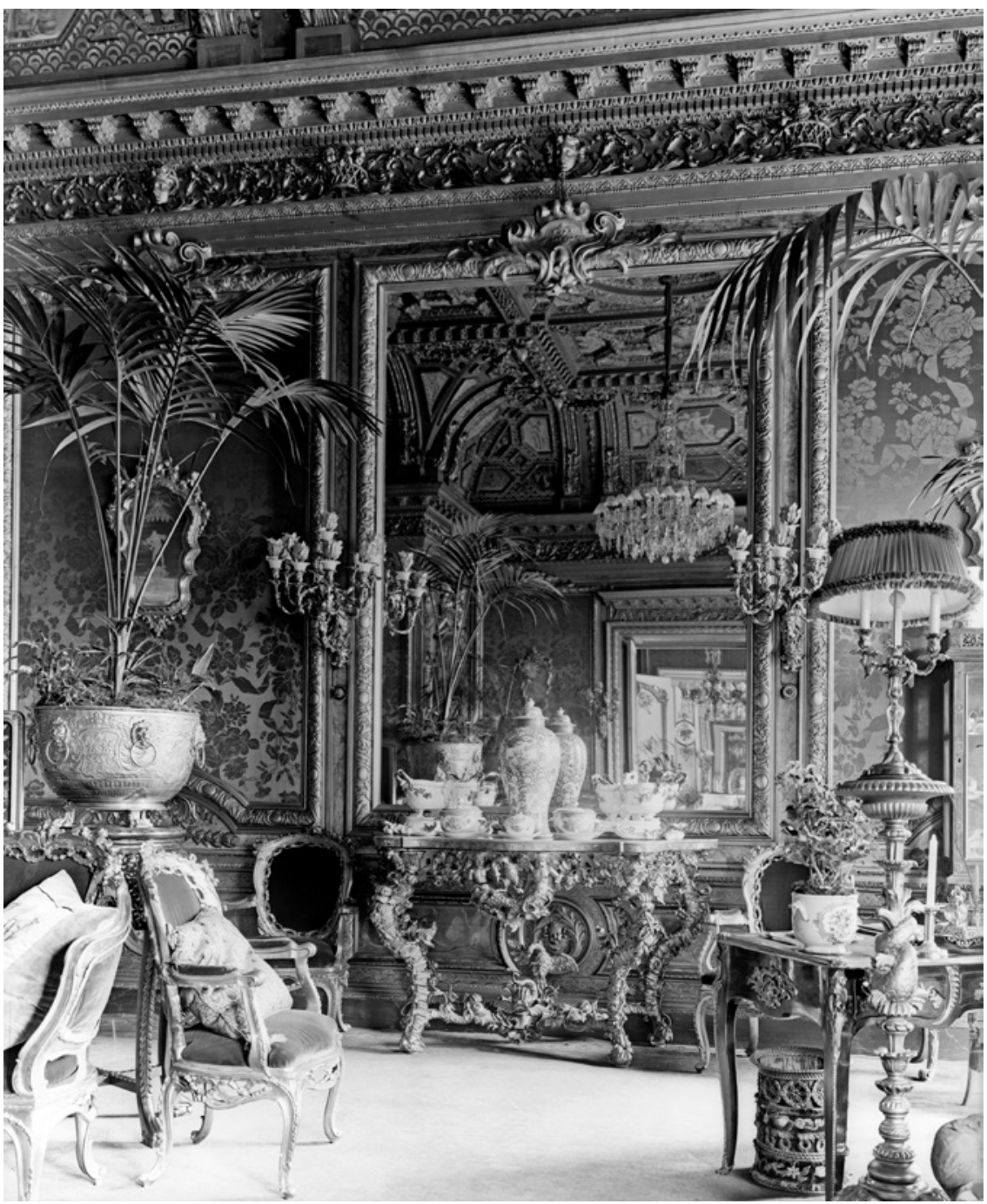

FIGURE 7.4 Anon., The Drawing Room, Wimborne House, 22 Arlington St., Mayfair, formerly Hamilton House and bought from the Dukes of Hamilton in 1870 by Sir Ivor Bertie Guest, ironworks owner, 1902. London, Country Life Picture Library (C) COUNTRY LIFE PICTURE LIBRARY

Alfred de Rothschild (1842-1918) were considered to be finer than the originals at Chantilly. However, diaries written at the time also show that this display of wealth was as much envied and admired as denigrated. A telling comment about Algernon Borthwick, 1st Baron of Glenesk (1830-1908) and owner of the Morning Post, gives part of the rationale for the wealthy: 'He is the friend and 
host of his Sovereign, not because he owns the Daily Telegraph but because he lives like a lord, and with lords and possesses first class shooting.' The plutocrats of the late nineteenth century, who had made their money in manufacture, brewing, railroads, shipping, banking — whether British, South-African, American or Jewish — could choose the style of the French eighteenth century and know that they were living at the same level of luxury as the royalty and aristocracy of the past. Ferdinand de Rothschild, who supported the Liberal government and as a Jew fought for Jewish emancipation, was a great admirer of French art and culture although not of its politics. For him the rise of the new rich created 'a new centre of attraction (that) has been formed on the ruins of the old, produced by the very action of the democracy.' Through their collections they could offer examples of taste and discernment, which could even 'lead to the social and political development of a future age. ${ }^{66}$ Ferdinand bought his treasures at aristocratic sales as part of the inevitable process of democracy. Nonetheless, he too used Waddesdon to entertain the society of his day, including the king. However, for Ferdinand there was another appeal of collecting French eighteenth-century works of art. Modelling himself on George IV and William Beckford, he saw himself as a prince of connoisseurship with the wealth to surround himself by the finest objects.

\section{Skill and Finish}

For Ferdinand de Rothschild, as for George IV, the eighteenth century in France was the period when the arts reached their peak. The names of André Charles Boulle and Riesener brought the English collector directly into the salons and elegant society of the eighteenth century, and for many French luxury goods represented the highest quality. The descriptions of furniture by Boulle and Riesener always emphasised the quality of the workmanship as well as the elegance, magnificence and costly qualities they held. It is perhaps not surprising that at a time when painters and art critics admired the detailed execution of such artists as Maclise or Mulready, Landseer or Lord Leighton, the same attributes were admired in furniture. ${ }^{67}$

66 Rothschild, "The Expansion of Art," 57.

67 These highly finished contemporary paintings were collected by many of the leading figures in Britain, from Queen Victoria, who most notably patronised Landseer, to the newly-rich industrialists. Nonetheless it is often assumed that few aristocrats collected contemporary art, so the sale of the collection of the Countess of Blessington in 1849 is particularly interesting for its combination of French furniture and contemporary British artists. The Costly and Elegant Effects including the Magnificent Furniture, Rare Porcelain, 
An added dimension was given to the taste and acquisition of French decorative furniture when national pride was identified with excellence in the arts. Success in the arts was part of the nationalist competition for excellence. For example, in 1875, when debating the proposal for the Royal Academy to exhibit in the Philadelphia International exhibition, the arguments put forward to the Privy Council to support the costs of the exhibit were that 'British Art has hitherto made a very poor show at all International Exhibitions, while foreign countries like France and Belgium have always been well represented; and the result is that whereas Belgian and French pictures are well-known and command a sale all over Europe, English Pictures are but little known and esteemed out of England.' ${ }^{68}$ This was also the concern for the decorative arts, where there were frequent representations that England needed to improve its quality of design in order to compete with other countries. Emulation of French furniture was considered by some, though by no means all, critics to be a way to provide inspiration for contemporary British design.

Ferdinand de Rothschild described the French Revolution as bringing to England 'the priceless and countless works of art, the heirlooms of centuries.' Moreover, for him, through this 'dissemination of ancient and foreign works of art [...] the multitude have been made conversant of their beauty and usefulness, that has opened out a new vista of refinement and industry.' 69 As a result England had become the centre of this market. Ferdinand thus combined the most admired qualities of the period-excellence in workmanship and beauty of design - with their beneficial influence on British life and culture. In this he was followed by John Jones, whose bequest to the Victoria and Albert Museum of his collection of French works of art was made to bring these qualities before the English public. ${ }^{70}$ In the catalogue describing the collection, the author goes out of his way to show how Jones was contributing to the nation's interest by providing works of inestimable value, both artistic and financial. Through this donation, it was argued, Britain could reach the same levels of quality as her competitors (Fig. 7.5).

Sculpture in Marble, Bronzes and an Assemblage of Objects of Art and Decoration [...] Collection of Ancient and Modern Pictures [...] from Gore House, sold by Mr. Philips on Monday, 7 May 1849 and twelve subsequent days.

68 Guillaume Evrard, "English Pictures Are but Little Known and Esteemed Out of England': The Royal Academy of Arts and the 1878 Paris Exposition Universelle," in Marketing Art in the British Isles, 1700 to the Present: A Cultural History, eds. Charlotte Gould and Sophie Mesplède (Aldershot: Ashgate, 2012), 211-26.

69 Rothschild, "The Expansion of Art," 57.

70 See the introduction to the catalogue of the John Jones Collection: Handbook of the Jones Collection in the South Kensington Museum (London: Chapman and Hall, 1883), 77-112. 


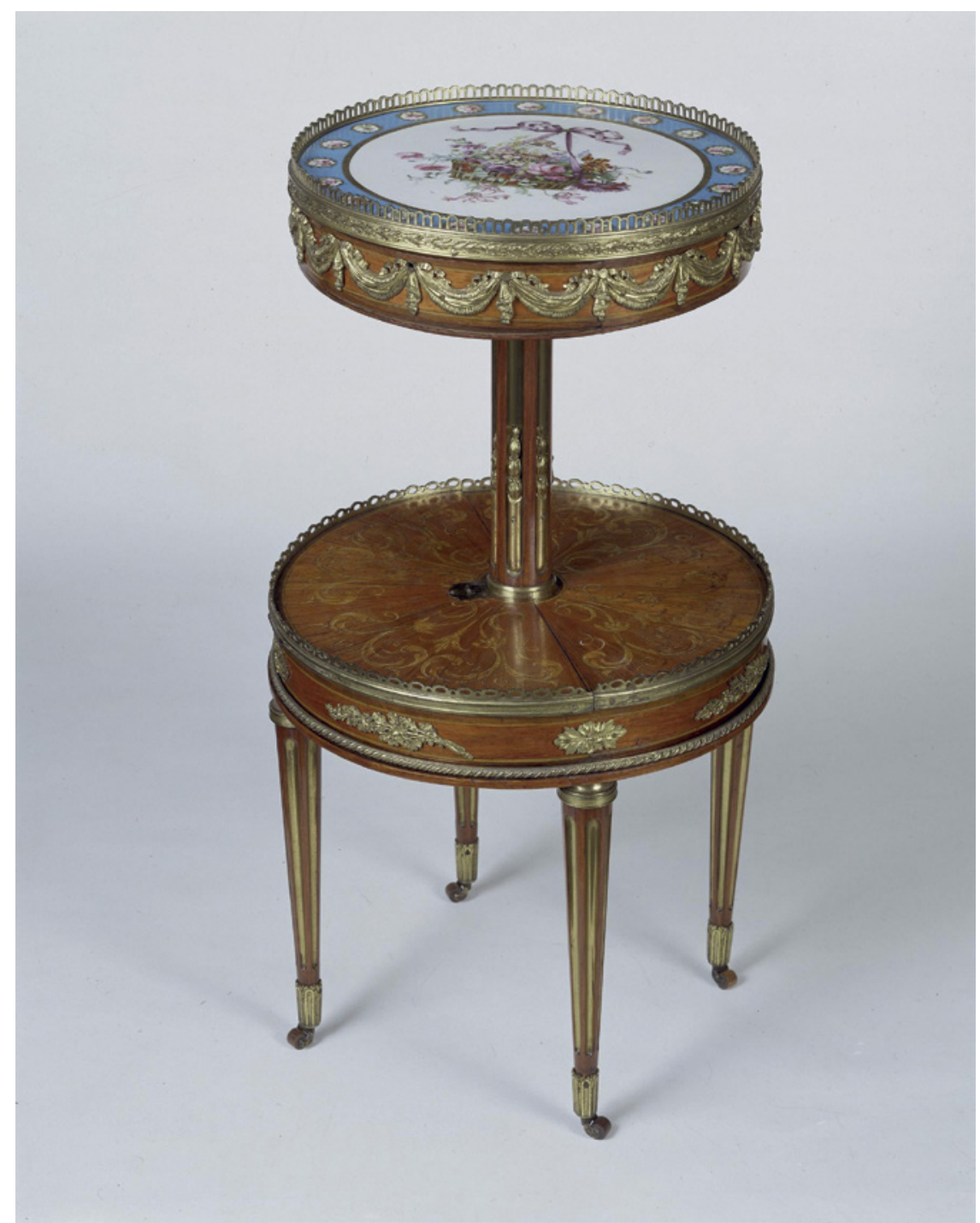

FIGURE 7.5 Martin Carlin, Worktable bequeathed by John Jones and said to have belonged to Marie Antoinette, veneered in tulipwood, purplewood, sycamore and boxwood on a carcase of oak, c. 1775. Gilt-bronze mounts, the top set with a porcelain plaque, $77 \times 42 \times 36.8 \mathrm{~cm}$. London, Victoria and Albert Museum

(C) VICTORIA AND ALBERT MUSEUM 
When Edith Wharton emphasised the fact that, in the past, works of art were deemed valuable because of their design and not because of their workmanship, she implicitly referred to the dominant emphasis on skill and manufacture as the chief aesthetic value. In fact this may account for another paradox, which is that very often modern copies were priced more highly than the antiques, partly because of the contemporary costs of the craft and partly because the modern would be newer, more lavish and possibly more comfortable.

The emphasis on finish and skill of original eighteenth-century French decorative arts seems crucial in accounting for the taste for French decorative arts and sets it apart from other historical revivals of the nineteenth century, placing the collecting of French works of art within a national British demand for finish and perfection. Lady Dilke, in her introduction to the furniture catalogue of the newly created Wallace Collection, furthermore separated the political conditions under which French eighteenth-century furniture was produced and emphasised that:

These are considerations which one would desire to put in the first place before the reader to whom this introduction is addressed. Because at the present time-when the works of the eighteenth century and especially the latter half of that century are inordinately popular-it is necessary to insist on the fact that their chief claim to admiration lies in the measure of the style and distinction which they have attained in virtue of the taste and admirable training of their makers. This is the lesson which the great store, garnered within these walls, is aptly calculated to teach. Furthermore I would say that beautiful things may be rare and costly, but rarity and cost are not in themselves excellencies.

The truth is that the exact appreciation of work, which in all its varied forms is the product of finished skill perfected in historic traditions and controlled by critical tastes, requires incessant and steadily directed effort of the judgment and constant discipline of the powers of observation. ${ }^{11}$

71 Émile Molinier, with an introduction by Lady Dilke, The Wallace Collection (objets d'art) at Hertford House (London: Manzi, Joyant \& Co, 1903), originally published in French as: Émile Molinier, La Collection Wallace: meubles et objets d'art français des XVII et XVIII siècle (Paris: E. Lévy, 1902). 


\section{Cosmopolitanism: The French Style as an Expression of National Pride}

In 1886 T.H. Escott, writing under the guise of a foreign visitor to England, commented:

British cosmopolitanism shows itself in its rapid assimilation of the social ideas of other countries and in its heroic struggle to rise superior to the hampering restrictions of insular respectability. True it still possesses its own excellent common sense, but even this immense virtue is beguiled by the desire of those who possess it to prove that they are without its prejudices. London society is thus a society in a state of solution. ${ }^{72}$

The use of the term 'cosmopolitan' brings another dimension to the taste for French, and indeed for foreign goods found in Britain during the nineteenth century. Arguably it underlies the enduring market for works of art at both the highest and more ordinary levels of society. One of the hallmarks of the nineteenth-century drawing room, the mixing of different types of decoration and time periods in a single space, became an example not just of wealth but also of the quality of British society. Disraeli's somewhat mocking tone in Henrietta Temple reflects the mixed appreciation of this historical medley: 'and then they were ushered into a drawing room of Parisian elegance: buhl cabinets, marqueterie tables, hangings of the choicest damask suspended from burnished cornices of old carving. The chairs had been rifled from a Venetian palace; the couches were part of the spoils of the French revolution. ${ }^{73}$ Disraeli's fictional drawing room could be found in many of the houses described in this essay: few collections were as concentrated on French works of art as those of George IV, the Marquess of Hertford or Ferdinand Rothschild. More typical, as has been discussed above, collections reflected an eclectic mixture of furnishings from myriad dates and countries. At Stowe, alongside the French furnishings, there were also a striking number of Italian cabinets and tables in the drawing rooms and the rooms used for entertainment, and a German cabinet in metal marquetry placed in the state bedroom was considered one

72 Thomas Hay Sweet Escott, Society in London, by a Foreign Resident (London: Chatto \& Windus, 1886), 24.

73 Benjamin Disraeli, Henrietta Temple: A Love Story (London: Henry Colburn, 1837), 350, quoted in: Crook, The Rise of the Nouveaux Riches, 173. 
of the most important items in the sale. ${ }^{74}$ The Hamilton Palace sale notably included important works of Italian, Russian or other continental origins alongside famous French pieces. Perhaps even more importantly, this mixing and melange of styles and materials can also be found in the sale catalogues of London houses belonging to not only the nobility, but also those described as 'a gentleman' or residents in fashionable areas of central London. The catalogues of the contents of their houses repeat the same eclectic mixtures as in those of the greater. Thus in sale catalogues, in addition to the concentration on French decorative arts, one also finds antiques from other countries, particularly Italy. ${ }^{75}$

Justifying, or at least explaining, the practice of displaying and living in surroundings which were eclectic in their style and international in their origin, should be seen within the context of the debate about Britain's international position in the world. It is by drawing on the discussions about cosmopolitanism that the resolution of the appropriation of a foreign style to formulate a British identity can be addressed. The term, as has been extensively discussed in recent writings on Victorian literature and identity, has many contradictory facets related to contemporary political and economic debates. ${ }^{76}$ Linked strongly to the debate over national identity, the issues of patriotism and nationalism and their relationship to the ideal of the "citizen of the world" developed strongly in the early nineteenth century. 'Cosmopolitanism' as a term was used by Coleridge in opposition to nationalism in The Friend in $1809 .{ }^{77}$ At the

74 Stowe Catalogue, Second days sale, lots 221-224 describes Venetian chairs from the Doge's palace and lots 253 and 254 were Florentine pietra dura cabinets. These were in the Duchess's drawing room and were displayed alongside a marquetry table, several gilt pier tables and a 'buhl' table. Ninth days sale, lot 1146 was a German marquetry cabinet, which at $£_{24} 615$ s was one of the most expensive items at the sale.

75 For example the stock of a Mr. Pratt boasted not only Louis XVI cabinets mounted by Gouthière, but also an astronomical clock from the royal palace of Turin and a suite of furniture from the Palace of Naples.

76 There has been much written about cosmopolitanism in general and its associations in nineteenth-century literature. See: Tanya Agathocleous and Jason R. Rudy, "Victorian Cosmopolitanisms: Introduction," Victorian Literature and Culture 38, no. 2 (2010): 389-97. This essay takes the term from this historical perspective and not from current sociological or socio-political viewpoint. However, for an overall introduction, a useful summary is found in: Victor Roudometof, "Transnationalism, Cosmopolitanism and Glocalization," Current Sociology 53, no. 1 (2005): 113-35.

77 Esther Wohlgemut, Romantic Cosmopolitanism (Basingstoke: Palgrave, 2009), 3-4. Wohlgemut argues that in fact the bipolarity between nationalism and cosmopolitanism argued by Coleridge in The Friend in 1809 was modified later in the essay to show that the two were seen as mutually constitutive and therefore non-oppositional. 
same time, for the Edinburgh Review a cosmopolitan understanding of politics was based on an international approach to economics. ${ }^{78}$ As it appeared in the writings of John Stuart Mill, in 1848 the term was given a more qualified, even negative use, on the one occasion he refers to cosmopolitanism itself: 'A tendency may, even now, be observed towards such a state of things; capital is becoming more and more cosmopolitan. ${ }^{79} \mathrm{He}$ continued to argue that such cosmopolitan freedom may not be possible in the unequal economic world of the British Empire. Mill's negative use of the word was not taken up by a number of Victorian writers, many of whom used the term to argue for a more universal and international understanding of the world. ${ }^{80}$ The term 'cosmopolitan,' as can be seen in the several journals that used it in their titles, could be used for various purposes and agendas, as the different stances in their editorial perspectives demonstrate. The short-lived Cosmopolitan Review (1861) followed the universal principles in the term; its writings aimed at bringing harmony to European policies. The weekly publication Cosmopolitan (1865-76) held a more imperialist viewpoint, writing about the English colonies. Cosmopolis: An International Review (1896-8), on the other hand, was more ambitious and international in its scope, trying to create networks between cities by publishing articles about the arts in Paris, London and New York. ${ }^{81}$

The concept of cosmopolitanism has not traditionally been linked with the types of interiors described above, but rather with the reform movements for English taste. Both Mary Haweis and her contemporary Lucy Orrinsmith wrote guides on interior decoration for the homeowner, ${ }^{82}$ arguing that drawing on the past or from different cultures brought individuality to the home and that such eclecticism could achieve the highest form of decoration. These treatises were intended to deal with exactly the mixture of different styles by showing how, through careful disposition, a well-balanced interior could be achieved in the readers' homes. Judith Neiswander argues that this emphasised the need for individuals to show their individuality and as such was linked to the lib-

\section{$78 \quad I d ., 52$.}

79 John Stuart Mill, Principles of Political Economics, vol. 2 (London: John W. Parker, 1848), chapter XVII, 1.

8o Tanya Agathocleous, Urban Realism and the Cosmopolitan Imagination in the Nineteenth Century: Visible City, Invisible World (Cambridge: Cambridge University Press, 2011), 58-9.

81 Agathocleous, Urban Realism, 54-67.

82 Lucy Orrinsmith, née Faulkner, was an artist who before she married worked for Morris \& Company and was a close friend of Morris, who advised her in the writing of her book, The Drawing Room: Its Decoration and Furniture, which was published in November 1877. See: Emma Ferry, "The Other Miss Faulkner': Lucy Orrinsmith and the 'Art at Home Series," The Journal of William Morris Studies 19, no. 2 (2011): 47-64. 
eral movements at the end of the nineteenth century and to the concept of free trade. Cosmopolitanism thus manifested itself in the choice of objects to decorate the interior, objects which came from all over the world. ${ }^{83}$ The type of cosmopolitan interior argued by Neiswander to have been part of a liberal, aesthetic creation was certainly far from the historicist interiors in which Boulle furniture, Italian cabinets and carved console tables enriched an already opulent room, possibly even one decorated with French Louis XV boiseries, such as those at Waddesdon Manor or the London townhouses already described. Although these writers, espousing the freedom to choose the best examples from all parts of the world, did not include examples of the French style-far from it - the very arguments involved in presenting the virtues of a cosmopolitan, free-ranging approach to design provided opportunities for critics to accept certain elements of French furniture, in particular the skill of artisans from the past.

Furthermore, cosmopolitanism could be linked to Britain's destiny and importance. Thus in the discussion which surrounded the Great Exhibition, for example, abundant use could be made of Kant's rhetoric of world peace, turning it to argue that Britain, with its industrial supremacy, would lead the world towards its egalitarian destiny—not least by aligning its territories with the progressive trajectory of European civilisation. 'What is more natural than that the first exhibition of the Works of Industry of all Nations should take place among a people which beyond every other in the world is composed of all nations' was only one of many such statements of pride in the wealth and cosmopolitanism of the nation. ${ }^{84}$ It is in this sense of cosmopolitanism that the collection of the Ancien Régime may be most closely associated. For the owners of these mansions, the mixture of antiques from international sources reflected cosmopolitanism as an expression of pride and national supremacy. The drawing rooms of the English could thus demonstrate the power of the British nation to own works of art from all countries, united under one roof. Whatever one's means, cosmopolitanism created the final stage in British perception of the revived French style, placing taste, wealth and national pride on display in the drawing room.

83 Judy Neiswander, The Cosmopolitan Interior: Liberalism and the British Home 1870-1914 (New Haven - London: Yale University Press, 2008), 8-14.

84 Agathocleous, Urban Realism, 37. 


\section{Conclusion}

The long-standing emulation of French style, already well established in the eighteenth century, gave it an internationalist acceptability, which during the nineteenth century came to stand for wealth and luxury. In England emulation was characterised by an interest in antique works of art; thus eighteenthcentury French furniture played a significant role in the interiors of the great houses. The motives to collect French furniture meant that the market continued long after its beginnings in the first part of the century. Obviously an important factor in the fashion and taste for furnishing houses in this style involved issues of emulation and copying. Nonetheless the choice to acquire French furniture and works of art signalled more than mere copying. French and later British dealers had pushed the market for French works of art onto the English scene immediately after the Revolution and maintained that market throughout the century. The connections between English and French dealers made high quality pieces available to British collectors, while in France there was no real market until decades later. However, the enduring success of the French style in the drawing rooms of Britain had deeper roots, thus ensuring a continuous demand for eighteenth-century French works of art by not only the wealthiest in the land, but also by those who aspired to emulate their taste. Through their ready acceptance of the French style as an expression of their position, English aristocrats appropriated the art of their enemy, paradoxically by giving it both an English as well as an international meaning. The desire to emulate and to appropriate the style of the Ancien Régime was based on various and sometimes conflicting motives, but its importance in the formation of the British sense of identity must be uniformly appreciated. The style of the Ancien Régime became the style of the plutocrats of the late nineteenth century who were both British and international. It thus represented a recognised form of wealth and taste both internationally and nationally. As such it can be argued that the reasons for acquiring French works of art moved beyond emulation to deeper motives of pride in the cosmopolitan position of Britain, in which the best of both Europe and the rest of the world could be brought to the country and where the British collector could rejoice in owning the finest works of art from Europe. At a time when the past provided contemporary artists with inspiration, French furniture was also expected to provide a standard to be emulated by British craftsmen. Through its emphasis on the combination of skill and design, French furniture appealed to the nineteenth-century collector and made it acceptable throughout society. It was this that supported the market for these works of art, making them not just collectors' items, but fundamental to every fashionable drawing room. To quote Escott again: 
There is, one is told, no waste in nature and what Paris, since the fall of the Empire, has lost, London has gained. I do not say that everyone goes to London now as all the world went to Paris once; but the British capital today approaches nearer to the Paris of fifteen or twenty years ago than any other capital of the world. London is not the most beautiful, the most splendid or even the most convenient city but it is pre-eminently the smart metropolis of Europe. ${ }^{85}$

\section{References}

Agathocleous, Tanya. Urban Realism and the Cosmopolitan Imagination in the Nineteenth Century: Visible City, Invisible World. Cambridge: Cambridge University Press, 2011.

Agathocleous, Tanya, and Jason R. Rudy. "Victorian Cosmopolitanisms: An Introduction." Victorian Literature and Culture 38, no. 2 (2010): 389-97.

Anderson, Benedict. Imagined Communities: Reflections on the Origin and Spread of Nationalism. London: Verso, 1983.

Appadurai, Arjun. Modernity at Large: Cultural Dimensions of Globalisation. Minneapolis: University of Minnesota Press, 1996.

Arrowsmith, Henry, and Aaron Arrowsmith. The House Decorator and Painter's Guide. London: Thomas Kelly, 1840.

Bailey, Colin. "Conventions of the 18th-Century Cabinet de Tableaux: Blondel d'Azincourt, la premiere idée de la Curiosité." Art Bulletin 69 (1987): 431-7.

Baulez, Christian. “Tout Europe tire ses bronzes de Paris." In Bernard Molitor, 1755-1833: ébéniste parisien d'origine luxembourgeoise, edited by Ulrich Leben, 77-101. Ville de Luxembourg: Galerie d'art de la Ville de Luxembourg, Villa Vauban, 1995.

Bayly, Christopher Alan. The Birth of the Modern World 1780-1914: Global Connections and Comparisons. Oxford: Oxford University Press, 2004.

Bayly, Christopher Alan et al. "AHR Conversation: On Transnational History." The American Historical Review 111, no. 5 (December 2006): 1441-64.

Beurdeley, Michel. De Versailles à Paris: le Destin des collections royales. Paris: Centre Culturel du Panthèon, 1989 .

Beurdeley, Michel. La France à l'encan-Exode des objets d'art sous la Révolution. Fribourg: Office du Livre, 1981.

Carlton House: The Past Glories of George IV's Palace. London: The Queen's Gallery Buckingham Palace, 1991.

85 Escott, Society in London, 24. 
Cooper, Nicholas. The Opulent Eye: Late Victorian and Edwardian Taste in Interior Design. London: Architectural Press, 1976.

Cordier, Sylvain. Bellangé ébénistes: un histoire du goût au XIXe siècle. Paris: Mare et Martin, 2012.

Crook, Joseph Mordaunt. The Rise of the Nouveaux Riches: Style and Status in Victorian and Edwardian Architecture. London: John Murray, 1999.

Davillier, Charles. Vente du Mobilier du Château de Versailles pendant le Terreur. Paris, 1877.

De Bellaigue, Sir Geoffrey. "Martin-Eloy Lignereux and England." Gazette des beauxarts 71 (1968): 283-94.

De Bellaigue, Sir Geoffrey. "Edward Holmes Baldock I." Connoisseur 189 (August 1975): 290-9.

De Bellaigue, Sir Geoffrey. "Edward Holmes Baldock II." Connoisseur 190 (September 1975): 18-25.

De Bellaigue, Sir Geoffrey. "George IV and French Furniture." Connoisseur 195 (June 1977): 116-25.

De Bellaigue, Sir Geoffrey. "Daguerre and England." In Bernard Molitor, 1755-1833: ébéniste parisien d'origine luxembourgeoise, edited by Ulrich Leben, 157-79. Ville de Luxembourg: Galerie d'art de la Ville de Luxembourg, Villa Vauban, 1995.

De Bellaigue, Sir Geoffrey. "Phillippe-Claude Maëlrondt, Supplier to George IV." Burlington Magazine 146 (2004): 386-95.

Demetrescu, Colin. "Le Cabinet de Boulle du duc de Buccleuch: une énigme Resolue." Dossier de l'Art, no. 224 (2014): 30-59.

De Rothschild, Ferdinand. “The Expansion of Art.” In The Fortnightly Review, edited by T.H.S. Escott, 55-69. London: Chapman and Hall, 1885.

De Vries, Jan. The Industrious Revolution: Consumer Behaviour and the Household Economy, 1650 to the Present. Cambridge: Cambridge University Press, 2008.

Dilke, Lady. "Introduction." In The Wallace Collection (objets d'art) at Hertford House, Émile Molinier. London: Manzi, Joyant \& Co., 1903.

Eagles, Robin. Francophilia in English Society. Basingstoke: Macmillan, 2000.

Eastlake, Charles. Hints on Household Taste in Furniture, Upholstery and other Details. London: Longman, Green \& Co., 1869.

Eschapasse, Anne. "William Beckford in Paris, 1788-1814: 'Le Feste Solitaire.” In William Beckford 1760-1844: An Eye for the Magnificent, edited by Derek Ostergard, 99-115. New Haven - London: Yale University Press, 2001.

Escott, T.H. Society in London, by a Foreign Resident. London: Chatto \& Windus, 1886.

Evrard, Guillaume. "English Pictures Are but Little Known and Esteemed Out of England': The Royal Academy of Arts and the 1878 Paris Exposition Universelle." In Marketing Art in the British Isles, 1700 to the Present: A Cultural History, edited by Charlotte Gould and Sophie Mesplède, 211-26. Aldershot: Ashgate, 2012. 
Ferry, Emma. “The Other Miss Faulkner': Lucy Orrinsmith and the 'Art at Home Series.” The Journal of William Morris Studies 19, no. 2 (Summer 2011): 47-64.

Friedman, Joseph. Spencer House: Chronicle of a Great London Mansion. London: Zwemmer, 1993.

Hall, Michael. Waddesdon Manor: The Heritage of a Rothschild House. New York: Harry Abrams, 2002.

Handbook of the Jones Collection in the South Kensington Museum. London: Chapman and Hall, 1883 .

Hughes, Peter. The Wallace Collection Catalogue of Furniture. London: Trustees of the Wallace Collection, 1996.

Ireland, Ken. Cythera Regained: The Rococo Revival in European Literature and the Arts, 1830-1910. Madison: Fairleigh Dickinson University Press, 2006.

Macdonald, Simon. “Transnational History: A Review of Past and Present.” January 2013. http://www.ucl.ac.uk/cth/objectives/simon_macdonald_tns_review.

Marshall, F. French Home Life. Edinburgh - London:William Blackwood and Sons, 1873.

Mill, John Stuart. Principles of Political Economy with Some of their Applications to Social Philosophy. London: Longmans, Green, Reader, and Dyer, 1867.

Morris, Edward. French Art in Nineteenth-Century Britain. New Haven - London: Yale University Press, 2005.

Neiswander, Judy. The Cosmopolitan Interior: Liberalism and the British Home 1870-1914. New Haven - London: Yale University Press, 2008.

Passavant, Johann David. Tour of a German Artist in England, With Notices of Private Galleries, and Remarks on the State of Art. London: Saunders and Ottley, 1836.

Pavoni, Rosanna, ed. Reviving the Renaissance: The Use and Abuse of the Past in Nineteenth-Century Italian Art and Decoration. Cambridge: Cambridge University Press, 1997 .

Pazaurek, Gustav E. Dreierlei Rokoko: Ausstellung im Königlich Württ. LandesGewerbemuseum Stuttgart 1909/Katalog im Auftrag der Königl. Zentralstelle für Gewerbe und Handel. Stuttgart: Klett \& Hartmann, 1909.

Pradère, Alexandre. "Lerouge, Le Brun, Bonnemaison: The Role of Art Dealers in the Commerce of Boulle Furniture from the Revolution to the Restoration." Revue de l'Art 184 (2014): 47-62.

Roberts, Sir Hugh. For the King's Pleasure: The Furnishing and Decoration of George IV's Apartments at Windsor Castle. London: Royal Collections, 2001.

Robinson, John Martin. The Wyatts: An Architectural Dynasty. Oxford: Oxford University Press, 1979 .

Roudometof, Victor. “Transnationalism, Cosmopolitanism and Glocalization.” Current Sociology 53 (2005), 113-35.

Schmarsow, August. Beiträge zur Ästhetik der Bildenden Künste. Barock und Rokoko. Leipzig: S. Hirzel, 1897. 
Semper, Gottfried. Der Stil in den technischen und tektonischen Künsten. Munich: F. Bruckmann, 1860 .

Smith, George. Cabinet-Maker and Upholsterer's Guide. London: Jones \& Company, 1826.

Springer, Anton. "Der Rococostil." In Id., Bilder aus der neueren Kunstgeschichte, vol. 2, 211-64. Bonn: A. Marcus, 1867.

Stevenson, Michael. Art and Aspirations: The Randlords of South Africa and their Collections. Vlaeberg: Fernwood Press, 2002.

Sykes, Christopher Symon. Private Palaces: Life in the Great London Houses. London: Chatto \& Windus, 1985 .

Tillyard, Stella. Aristocrats: Caroline, Emily, Louisa and Sarah Lennox, 1750-1832. London: Chatto \& Windus, 1994.

Turpin, Adriana. "Filling the Void: The Development of Beckford's Taste and the Market in Furniture." In William Beckford 1760-1844: An Eye for the Magnificent, edited by Derek Ostergard, 177-201. New Haven - London: Yale University Press, 2001.

Verlet, Pierre. "Chapeaurouge et les collections royales françaises." In Festschrift für Erich Meyer zum 6o. Geburtstag, 29. Oktober, 1957: Studien zu Werken in den Sammlungen des Museums für Kunst und Gewerbe, Hamburg, 286-94. Hamburg: Hauswedell, 1959.

Vertovec, Stephen. Transnationalism. Abingdon: Routledge, 2009.

Von Pückler-Muskau, Hermann. Tour in England, Ireland, and France, in the Years 1828, and 1829. [...] In a Series of Letters. By a German Prince. Translated by Sarah Austin. London: Carey, Lee and Blanchard, 1832.

Wainwright, Clive. “William Beckford's Furniture." Connoisseur 191 (April 1976): 290-7.

Wainwright, Clive. The Romantic Interior. New Haven - London: Yale University Press, 1989 .

Watson, Sir Francis. "Walpole and the Taste for French Porcelain." In Horace Walpole: Writer, Politician and Connoisseur, edited by Warren Hunting Smith, 185-94. New Haven - London: Yale University Press, 1967.

Wharton, Edith, and Ogden Jr. Codman. The Decoration of Houses. London: Batsford, 1898.

Wohlgemut, Esther. Romantic Cosmopolitanism. Basingstoke: Palgrave Hamilton, 2009. Yorke, James. Lancaster House: London's Greatest Town House. London: Merrell, 2001. 